\title{
VÁZLATPONTOK A TELEPÜLÉSMARKETING ÉRTELMEZÉSÉHEZ ÉS KIDOLGOZÁSÁHOZ
}

\author{
(Some sketch points for the contemplation and implementation of \\ settlement marketing)
}

\section{RECHNITZER JÁNOS}

A település fejlödésének és müködésének aktivitását számos módon érhetjük el. $\mathrm{Az}$ egyik ígéretes megoldás, hogy a rendelkezésre álló, vagy éppen a fejlesztésre kijelölt tényezöket széles körben megismertetjük, megkíséreljük felkelteni irántuk a piaci érdeklödést, s ezzel a keresletet. A másik, hogy az ott élö polgárokat egyre szélesebb körben bevonjuk a település fejlesztésébe, erősítve kötődésüket, részvételüket - netalán - anyagi és egyéb támogatásukat. A polgárok mellett a gazdasági szereplök, a különféle intézmények és szervezetek támogatásának elnyerése is fontos záloga lehet a telepuilést érintő fejlesztési programoknak, illetve az újabb üzemeltetési feltételek kialakításának. Az önkormányzatok tehát csak akkor vívhatják ki a polgárok, a gazdasági, társadalmi szereplök támogatottságát, ha a különféle politikai akaratok mellett vagy éppen azok eredöjeként képesek és alkalmasak a település értékeit, adottságait tudatosan és célirányosan megjeleníteni, illetve éppen ezen célcsoportok megelégedettsége szerint múködtetni a települést. Nem egyszerü feladat egyik oldalról megfelelni a polgárok és a lokális szereplök elvárásainak, miközben a másik oldalon az egész települést, annak értékeit és adottságait folyamatosan meg kell ismertetni a potenciális új aktorokkal, aztán segíteni azok megtelepedését, integrálódását. A telepuilésmarketing segítséget nyújthat ezen komplex feladat- és tevékenységrendszerhez.

\section{A klasszikus marketingtöl a településmarketingig}

Kotler (1991), a marketing egyik szellemi atyja azt mondja, hogy a marketing társadalmi és vezetési lépések láncolata, melynek során az egyének és csoportok termékeket és értékeket alkotnak s cserélnek ki egymás között, mialatt kielégítik szuikségleteiket és igényeiket. Az áruk és szolgáltatások világában a marketing mint szemlélet magában foglalja a termékek célirányos kifejlesztését, azok minőségi gyártását, eljuttatását a különféle csatornákon a fogyasztókhoz úgy, hogy azok szükségletei minél teljesebben elégüljenek ki. A marketing - miként azt a meghatározás is írja - társadalmi és vezetési lépések láncolata, egyben gondolkodási mód is, azaz a gazdasági rendszer olyan típusú irányítása, szervezése, vezetése, amellyel a kitüzött célokat a legteljesebb módon kívánjuk elérni. Az áruvilágban kidolgozott és alkalmazott marketing módszerek, mint új szemléletü vezetési, 
irányítási és szervezési megoldások alkalmazásra kerültek a nem gazdasági tevékenységekben is, így a különféle társadalmi akciókban (non-profit marketing), szociális szférákban (szociális marketing), a pártpolitikákban (politikai marketing), illetve az egyes nagy, komplex rendszerekben.

A közösségi marketing nem egy termékre, termékcsaládra irányul, hanem különféle érdekcsoportok között kíván valamilyen kapcsolatot, összhangot megteremteni az együttesen elfogadható célok érdekében. A „termék” itt sajátos, az lehet egy eszme, világkép, gondolkodásmód, de lehet a biztonság, a nyugalom stb. A cél a különféle nem materiális igények vagy éppen cselekvési formák, magatartási módok megismertetése, azok elterjesztése, érvényesülésük ösztönzése.

A településmarketing olyan irányítási, vezetési és szervezési megoldást $s$ egyben gondolkodási módot jelent, amely képes érvényesíteni és koordinálni a település egyes célcsoportjainak akaratát a mủködésben és a fejlesztésben, miközben ennek a komplex társadalmi, gazdasági, környezeti és szociális rendszernek az értékei, adottságai egyre szélesebb körben kerülnek megismerésre, tudatosításra.

A településmarketinghez kapcsolódó tevékenységek nemcsak feltételezik, hanem meg is követelik, hogy legyen a településnek fejlesztési programja, azaz a közösség tudja, hogy milyen adottságokkal rendelkezik, azokból a jövöben mit akar és képes kihozni. A fejlesztési célok éppen a marketing szemlélet miatt nem egymás mellett léteznek, hanem megvalósul azok integrációja, azaz létrejöhet az egymásra hatások tudatos kimutatása, az együttes hatásrendszerek érvényesülése, ami a tervezés hatásfokát növeli.

A fejlesztési célokat a településben található különféle célcsoportok határozzák meg. Ezek a célcsoportok a polgárok és a gazdasági szereplők különféle dimenziók szerint szervezödött együttesei lehetnek. A tömörülésük alapja az érdekazonosság, amelyet a szakmai kapcsolatok, az azonos tevékenységi módok, vagy éppen a megegyezö szervezeti rendszerek, értékrend, gondolkodási módok, fogyasztói rétegek stb. határoznak meg ( $I$. ábra).

A marketing szemlélet tehát:

- a tervezésben hozzájárul a település fejlesztési céljainak meghatározásához, azok integrálásához;

- a cselekvésben, a megvalósításban a fejlesztések érdekében segíti a különféle célcsoportok aktivizálását;

- az ellenörzésben, a visszacsatolásban regisztrálja és jelzi az eltéréseket, azok okait.

A fejlesztési koncepcióra épüló marketing stratégia a területi dimenzióban irányulhat egy településre, annak különféle változataira, így falura, kis-, közép- és nagyvárosra (városmarketing), de települések együttesére, kistérségekre, valamilyen összefüggó területi egységre vagy éppen megyére, (régiómarketing), illetve nagyobb területi egységekre, makrorégióra, országrészre. A területi egységek ugyanakkor szủkíthetők is, hiszen kidolgozható például egy belváros (citymarketing) vagy településrész marketing koncepciója is. A meghatározó az, hogy bármilyen területi, települési kombináció endogén forrásait 
Rechnitzer János: Vázlatpontok a településmarketing értelmezéséhez és kidolgozásához.

Tér és Társadalom, 9. 1995. 1-2. 5-16. p.

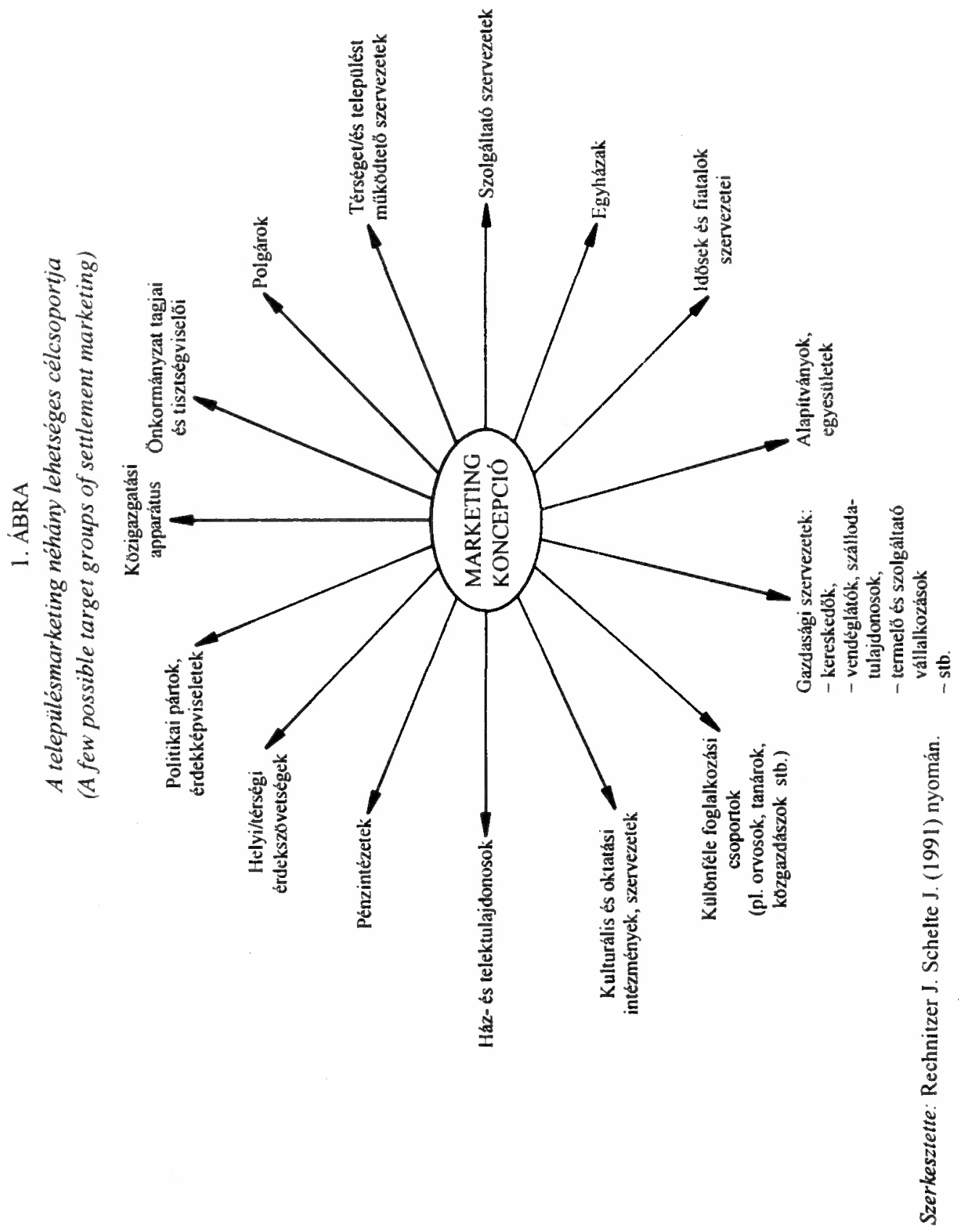


tárjuk fel, fejlesztési programját állítjuk is össze, éppen a marketing szemlélet és eszközök segíthetnek hozzá ahhoz, hogy a rendelkezésre álló forrásokat aktivizáljuk, azok szereplóit koordináljuk.

A hazai szakirodalomban a településmarketingre vonatkozó átfogó ismertetést, módszertani megalapozást nem találhatunk. Az önkormányzatok marketing szemléletú vezetését bemutató tanulmányon (Bányai $J .1993,1994$.) kívül csak a település arculat és image értelmezésével, illetve annak gyakorlati megjelenésével foglalkozó dolgozatok bukkannak fel a szaklapokban (Szakál Gy. 1993, Cséfalvay Z., Fischer W. 1990, Puskás F. 1994). A külföldi irodalomban viszont tallózhatunk a témakörhöz kapcsolódó írásokban, így összeállításunk alapját is ezek a dolgozatok jelentették (Schaller, U. 1993, Meffert, H. 1989, Schelte, J. 1991, Maier, J.-Troeger-Weiss, G. 1990). A településmarketing alkalmazása iránti igény a jövőben a településekben és térségekben megnő, hiszen a versenyhelyzet, a sikeres önkormányzati politika, vagy éppen a területi egység célirányos megjelenítése megkőveteli a korszerü fejlesztési és tervezési módszerek elterjedését, illetve az új irányítási és vezetési megoldások térnyerését.

\section{A településmarketing külsọó és belső meghatározói}

Láthattuk az előzőekben, hogy a településmarketinget mint gondolkodási, tervezési és cselekvési módot használjuk fel arra, hogy a fejlesztési céljainkat megvalósítsuk. Ezeket a célokat külső és belsö tényezők determinálják. Az előbbiek arra irányulnak, hogy a települést, annak adottságait a környezet és a világ megismerje, kellően értékelje, míg az utóbbi arra, hogy a helyi erőforrásokat aktivizáljuk, a különféle célcsoportok véleményét, akaratát, s egyben adottságait is felhasználjuk a fejlesztések érdekében.

A külső tényezők között fontos elem a versenyképesség fokozása. A gazdasági szereplök versenye mellett a települések is harcot folytatnak az új, az innovativ gazdasági szervezetek letelepítéséért, az új tevékenységek megjelenéséért. Miközben törekszenek ezen megújitást hordozó egységek telephelyi és müködési feltételeinek kiépítésére és azok megfelelỏ szintủ ajánlására. A települések versenyében már nemcsak a korábbi kemény tényezök, így a munkaerő költségei, a telekárak, a közmüdijak, a különféle helyi adók, támogatások játszanak szerepet, hanem az ún. puha tényezök is, vagyis a környezet minösége, a kulturális kínálat, a szabadidő és a pihenési lehetőségek, a minőségi lakásállomány, a helyi közlekedés szinvonala, a zöldterület, a településen az életminöség különféle hordozói (pl. közbiztonság, ellátórendszerek felszereltsége, intézményhálózat színvonala stb.). Egyre fontosabb tehát az adott településröl kialakult kép, az ottani életkörülményeket befolyásoló minőségi tényezők ismertsége, azok tudatos terjesztése. A település image-e az újdonságokért vívott küzdelemben egyre fontosabb tényezővé válik, hiszen az új, a letelepedni szándékozó vállalkozók és polgárok döntéseiknél ezen arculatból indulnak ki. 
A helyi kormányzatnak nemcsak a külső kapcsolatokat kell ápolnia a település lakosságával, hanem annak környezetében élö polgárokkal, valamint a különféle célcsoportokkal is állandó és folyamatos interakcióban kell lennie. Fontos regisztrálni azt, hogy:

- a polgárok elégedettek-e a helyi kormányzat müködésével;

- miként lehetne a polgárok igényeit jobban, szélesebb körben érvényesíteni, ezek milyen település müködési és fejlesztési faktorokban jelennek meg;

- miként lehet a polgárok véleményét, észrevételeit a döntések elökészítésében megjeleníteni;

- $\mathrm{s}$ végül hogyan lehet aktivizálni a polgárokat, megmozgatni őket egy-egy települési cél érdekében.

A településmarketing tehát a település adottságainak, értékeinek megismertetésére, azok terjesztésére irányul a tágan értelmezett környezetben, valamint a különféle gazdasági, társadalmi rendszerekben. Másik dimenziója maga a település, az ott élỏ polgárok és különféle alapon szerveződő célcsoportjaik, azok aktivizálása, megnyerése részben a fejlesztési irányok kidolgozásához, részben pedig azok célirányos megvalósitásához. A két metszet nem különülhet el egymástól, annak kapcsolata nemcsak szoros, hanem elválaszthatatlan is. Hiszen egy jól kidolgozott image belsö tartalom nélkül nem életképes, míg egy polgár- és vállalkozásbarát önkormányzat hírére megjelennek a le- és betelepedni szándékozó gazdasági szervezetek és polgárok.

\section{A marketing stratégia a településfejlesztési koncepcióban}

Jó és célirányos marketing stratégia csak akkor dolgozható ki egy településre, ha tudjuk, hogy milyen céljai, elképzelései vannak önmaga fejlődésére, azaz ha felvázoltuk a fejlődési pályát, meghatároztuk annak elemeit. A településmarketing arra tesz kísérletet, hogy ezt a sajátos termék és szolgáltatás kombinációt eladja, annak céljait, elképzeléseit megismertesse, s egyben ösztönözze a különféle szereplöket, hogy a kijelölt fejlesztési irányhoz kapcsolják erőforrásaikat, annak megvalósítását a maguk eszközeivel szolgálják, sőt stimulálják. Ehhez elengedhetetlen, hogy az adottságok ismertek legyenek, a település tudja, hogy hol a helye, legyenek egyértelmủ, megfogható célok, azok kellö alátámasztást, indoklást kapjanak. Tekintsük át a településfejlesztésre épüló marketing stratégia kidolgozásának lépéseit, hogy aztán a megvalósitás módszereit is megismerhessük (2.ábra).

\section{$A$ helyzetelemzés}

A kiinduló állapot minden stratégia alapja. Tudni kell, hogy milyen adottságokkal rendelkezünk, ezek közül melyek a megújitást hordozó elemek és melyek a kockázatot, a bizonytalanságot jelentő tényezök. Nem feledkezhetünk meg arról, hogy a település endogén forrásai közül melyek az erősek, a dominánsak, például a környezetünkhöz vagy 


\section{2. ÁBRA}

A marketing-mix elemei a helyi/térségi fejlesztésben

(The elements of the marketing mix in local/regional development)

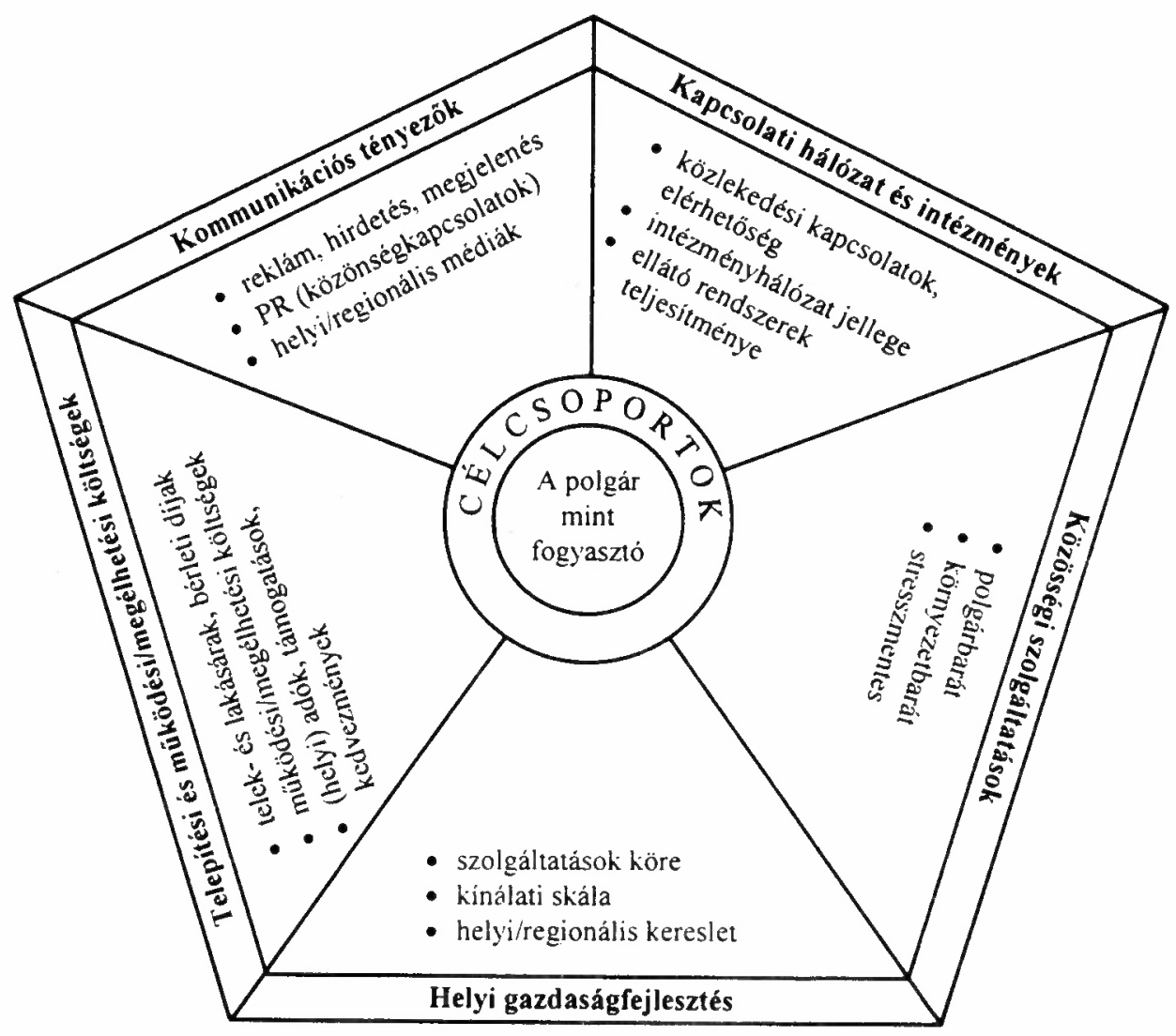

Szerkesztette: Rechnitzer J. 
egy másik hasonló jellegủ centrumhoz képest. Persze ennek ellenpontját, a gyenge elemek listáját is össze kell állítani, azokat a tényezőket, amik hiányosak, korlátozottak, kevésbé kiépitettek vagy csak elemeiben aktivizálhatók. Számba kell vennünk a település versenyképességét meghatározó faktorokat, illetve akadályozó elemeket.

Az elemzések döntő módszertani iránya az összehasonlítás, az egybevetés, az adottságok másságának, különleges voltának bemutatása, azok jellegének pontos meghatározása. Arra a kérdésre kell a választ megadni, hogy miben különbözünk más településektől, miért minket válasszanak a letelepedni szándékozók, miért maradjanak nálunk a vállalkozók és a polgárok.

Az adottságok és hiányosságok, gyengeségek és erősségek elemzése rendkívül sok információt kínál ahhoz, hogy meghatározzuk a település fejlesztésének irányait, kijelöljük jövőképének fóbb elemeit.

\section{A fejlesztés irányai, a célok meghatározása}

Ebben a szakaszban már a feltáruló ismeretek birtokában meg kell határozni, akár alternatív módon is - különféle szcenáriók felvázolásával -, hogy milyen jövőképet szánunk a telepủlésnek, annak melyek a legfontosabb elemei, alkotórészei. Kitérhetünk a versenyképesség fokozásának faktoraira, a különféle endogén források aktivizálására, a népesség potenciál növelésére és további számos településjellemző megújításának vagy éppen visszafejlesztésének irányára.

A marketing célokat is ebben a fázisban kell maghatároznunk, hiszen a különféle fejlesztési irányokhoz hozzá kell rendelnünk a település értékesítési, vezetési, szervezési céljait. Ilyen például a település új arculatához kapcsolódó image kialakítása, az ismertség sokoldalúbb megalapozása, a különféle célcsoportok elégedettségének növelése, a gazdasági szereplők biztonságának hosszú távú garantálása stb. A fejlesztési stratégia elemei tehát megkövetelik, hogy azok alkalmazásának rendszerét kijelöljük, amiáltal a településmarketing már biztos talajon áll, hiszen ismerjük magunkat, tudjuk mit akarunk a jövőben elérni. Mind ehhez hozzárendelhetők a megoldási módok, érvényesítési technikák.

\section{Stratégia és intézkedési terv}

A stratégia a célok megvalósítását szolgálja. Célszerü kiemelni a versenyképesség fokozására irányuló akciókat, mert ezek a külső és belső erőforrások széles körének a megmozgatását eredményezhetik, ahol aztán bőségesen alkalmazhatók a marketing eszközök. A finanszírozási feltételek nélkül nem készülhet stratégia, hiszen tudnunk kell, hogy mi áll rendelkezésre, milyen anyagi rendszerek segítik vagy éppen korlátozzák a céljaink megvalósítását. 
A marketing-mix már azokat a konkrét lépéseket, módszereket jelenti, amelyek a különféle célcsoportok felé irányulnak, hogy a kitüzött elképzelésekhez, fejlesztési irányokhoz kapcsolódjanak, azok tartalmát megvalósítsák, esetleg annak irányába mozduljanak el. A klasszikus marketing-mixben megfogalmazott termék-, ár-, elosztási és kommunikációs politika elemeit a települések sajátos jellege miatt át kellett alakítanunk, miközben a rendszerelemek kapcsolatát, azok kölcsönös feltételezettségét és viszonyát törekszünk hangsúlyozni (3. ábra).

Nézzük át a településre alakított marketing-mix elemeket:

3. ÁBRA

A marketing szemléletü településfejlesztés folyamata

(The process of the marketing-oriented settlement development)

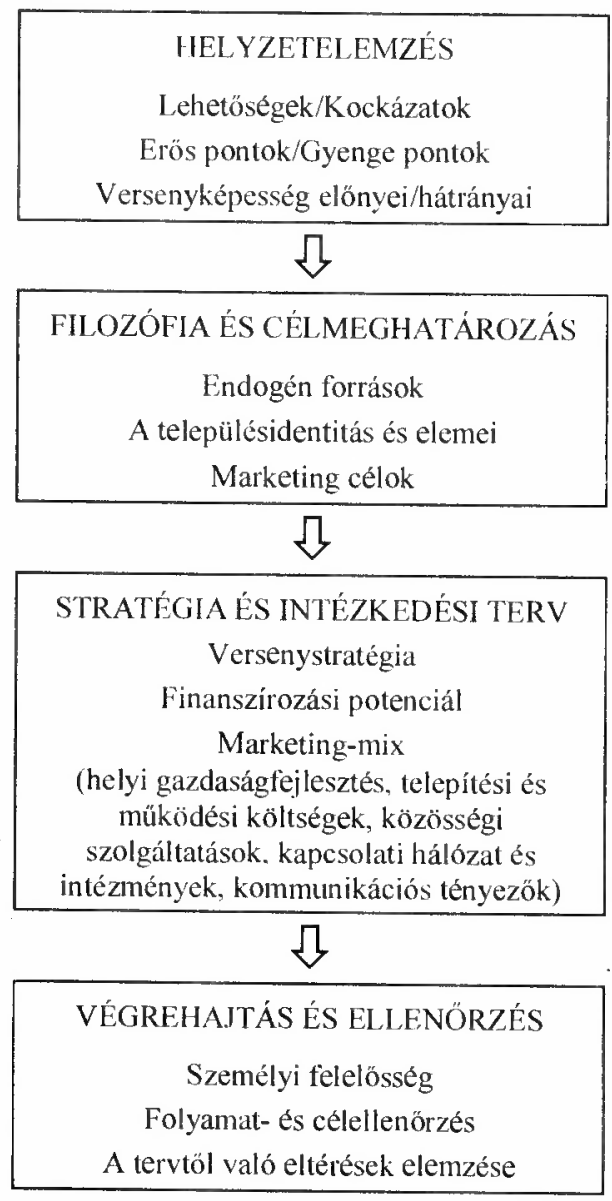

Forrás: Meffert, H. (1989) 
Rechnitzer János: Vázlatpontok a településmarketing értelmezéséhez és kidolgozásához.

Tér és Társadalom, 9. 1995. 1-2. 5-16. p.

TÉT $1995 \cdot 1-2$

Vázlatpontok a településmarketing értelmezéséhez és...

a) Helyi gazdaságfejlesztés

A település gazdaságának fejlesztése kiterjed szereplöinek ösztönzésére, a helyi gazdaság termékeinek ismertetésére, a településjelleg erősítésére ezen produktumokban és szolgáltatásokban. Tudatosítani és értékelni kell a helyi sikeres gazdasági tevékenységeket, hiszen a település neve, egyben értékei is kötődnek ezekhez a vállalkozásokhoz, termékekhez. A településben kialakult gazdasági magatartás ismertetése, annak terjesztése, az egyedi, a sajátos, a különleges légkör ösztönözheti a vállalkozások letelepedését. A helyi gazdasági kereslet élénkítése, a versenyeztetés, elismerés, a lokális gazdasági kapcsolatok ösztönzése, lehetőségeinek tágítása stb. hozzájárulhat a gazdasági szereplök ítéleteihez, s települési közérzetének alakításához. A helyi gazdasági klíma fontos eleme a marketing stratégiának, tehát mindenképpen éreztetni kell, hogy ebben a településben érdemes vállalkozni, itt megbecsültek, értékeltek a gazdasági szereplők.

b) Telepitési és müködési/megélhetési költségek

Nem lényegtelen, hogy milyen költségek merülnek fel az egyes gazdasági szereplőknél vagy éppen intézményeknél, polgároknál. A települések müködéséhez az egyes gazdasági szervezetektől erőforrásokat kell elvonni, ezért nem lényegtelen annak mértéke, de talán fontosabb, hogy felhasználása átlátható, megismerhetố legyen, illetve valamilyen módon szolgálja a vállalkozások érdekeit, bövítse azok akciótereit. A helyi adók mértéke és felhasználása, a támogatási rendszerek, de a telekárak, a bérleti díjak vagy éppen a kiskereskedelmi árak is fontos eszközei a település megítélésének, az arról alkotott kép alakításának (pl. drága vagy olcsó város).

c) A kommunikációs politika

A település értékeit, annak fejlesztési céljait, irányait meg kell ismertetni a lakossággal és a gazdasági, társadalmi környezettel. Ennek lehetnek közvetlen és közvetett eszközei. Közvetlen eszköze a reklám, a hirdetések, a célorientált települési bemutatkozások, az erre szervezett rendezvények, ismertetö anyagok kiadása és eljuttatása potenciális célcsoportokhoz. A közvetett eszközök tárháza is böséges. Itt kiemelendő a PR (Public Relations), amikor a település polgáraival, a különféle célcsoportokkal rendszeresen foglalkozunk, számukra információt, tájékoztatást adunk, a különféle akciókban megjelenítjük a fejlesztési célokat, utalunk azok fontosságára, abban az egyes szereplók súlyára. Ezeket az akciókat szolgálhatják a különféle települési kulturális és sportrendezvények, jubileumok, ünnepek, fesztiválok, illetve minden olyan tevékenység, amely által a településre, annak céljaira asszociálnak a jelenlegi és potenciális fogyasztók. A település kommunikációs politikáját határozottan szolgálják a helyi médiák, melyek folyamatosan hírt adnak a történésekről, erősen formálják a telepủlésröl alkotott képet, ugyanakkor segítenek az események szervezésében, terjesztésében.

\section{d) A kapcsolati hálózat}

A település nyújtotta szolgáltatások elérhetősége, megközelítése roppant lényeges szempont a fejlesztési programban kitüzött célokban. A helyi közlekedési hálózatok a településen belüli kapcsolatokat segítik, míg a külső hálózatok az intra- és interregionális együttmúködéseket ösztönzik. A különféle ellátó rendszerek színvonala, azok kapacitásá- 
nak mértéke is hat a település megitélésére, de a szűkebb vagy tágabb környezetével kialakitott kapcsolataira is.

e) A közösségi szolgáltatások

A település önkormányzata, annak szervezetei és hivatalai, intézményei, de a különféle közösségi ellátást végző vállalatok megjelenése, kapcsolattartási módjai, egyáltalán a polgárokhoz való viszonya alapvetően meghatározza a településröl alkotott képet. A településen müködő közösségi szervezetek tevékenységét jellemezze polgárbarát mentalitás, egyben legyenek környezetbarátok, azaz a település értékeit, adottságait tiszteljék, annak megóvásában példamutató módon járjanak el. Végül pedig a települési léttel összefüggö különféle tevékenységekben mérséklödjenek a stresszhatások, gondolunk itt például a közigazgatási ügyintézés gyorsitására, a személygépkocsik parkolására, a közbiztonság fokozására stb.

\section{Ellenơrzés és visszacsatolás}

A marketingszemléletủ településfejlesztés nem nélkülözheti a folyamatos regisztrálását annak, hogy a kitủzött célok miként valósultak meg, azoktól miben és mennyiben tértek el a végrehajtók. Mindezt a körülmények hatására tették-e vagy éppen gondatlanságuk, esetleg felkészületlenségük következtében, azaz mennyiben felelősek az eredmények elmaradásáért. Persze nemcsak a személyekre szabott feladatok figyelemmel kísérése lényeges, hanem a végrehajtás egész folyamatának ellenörzése éppen úgy, mint az egyes célok megvalósitásának értékelése vagy éppen annak vizsgálata, hogy milyen tényezők kényszeritették ki a tervtől való eltérést. A tervezés tehát csak akkor eredményes, ha rendszeresen visszacsatolással él a valóságról, de a körülmények változásáról is, majd ismét ezekhez igazítja a célokat, $s$ ennek megfelelöen módosítja a stratégiát, ami aztán a konkrét intézkedések átalakítását is magával hozza.

\section{A településmarketing alkalmazásänak alapelvei}

A fentebb vázolt elméleti és módszertani elvárások csak az alábbi feltételek esetében valósíthatók meg:

- A település rendelkezik fejlesztési koncepcióval, amit nemcsak az önkormányzati tényezők fogadnak el, hanem a település lakossága, annak különféle gazdasági, társadalmi, közösségi szereplöi is ismernek, söt elemeinek többségével azonosulnak.

- A településen belül a célcsoportok meghatározásra kerültek, s azok helye, szerepe egyértelmúen meghatározott és értelmezett mind a stratégiában, mind az intézkedési tervben. A siker, de a megvalósítás záloga is, hogy a település szinte minden befolyással rendelkező tényezője, szereplője tudja, hogy mire számithat a fejlesztés során és ezért mit kell vagy éppen lehet tennie. Természetesen a különféle célcsoportok más és más, többsé- 
gében eltérö érdekeket képviselnek, így számtalan érdekütközéssel, konfliktussal kell számolni a fejlesztési koncepcióban, majd elemeinek kidolgozása során. Az érdekek harmonizálását, összehangolását megfelelően kidolgozott marketing célok jól segithetik. Hiszen a település értékeinek megismertetése, az egyes elemek erösítése a település környezeti állapotának javítása vagy a polgárbarát önkormányzati müködés szintjén minden célcsoport elvárásaiban jelen van.

- A marketing eszközöknek és módszereknek, de magának a gondolkodási és cselekvési módnak széles alkalmazásával növelhetjük a fejlesztési célkitüzések sikerét. A marketing stratégia fókuszpontja az önkormányzatok s azok intézményeinek jó kapcsolata a polgárokkal. A település müködtetésének és fejlesztésének ügye ne csak a választások elött és után legyen fontos. A település jövőképe nem néhány ember vagy fél tucat érdekcsoport megegyezésével alakuljon $\mathrm{ki}$, hanem abban jelenjen meg a polgárok jelentősebb rétegeinek véleménye is. Ehhez rendszeres kapcsolattartásra, tájékoztatásra, együttmüködésre, kellö nyitottságra van szükség, s mindezeken túl a tevékenység minden szintjén a polgárbarát hivatalokra, intézményekre.

- A sikeres településmarketing megköveteli, hogy a település megjelenése egységes legyen. Nem eredményesek akkor az akciók, amikor a település egyik vagy másik intézménye, esetleg befolyásos célcsoportja más-más településképet, jellemzőt, esetleg annak egymástól alapvetően eltérő formáját (pl. logo, arculat, fontosabb adottságok szlogenjei, ismertetők, tájékoztatások stb.) alkalmazza. A koordináció döntő a marketing stratégiában, ennek centruma természetesen maga az önkormányzat, viselve az összehangolás, a célcsoportok folyamatos együttmüködésének minden terhét, $s$ anyagi következményeit is.

- Jó, jó gondolja az Olvasó, de ki szervezze, koordinálja a településmarketinget, a tevékenység hol helyezkedjen el az önkormányzati struktúrában, esetleg attól elkülönülten müködjön-e? Nos, erre az óhatatlanul felbukkanó kérdésre az egyik válaszunk, hogy a településmarketinget a település minden polgára, azok minden célcsoportja végzi, ám annak irányításában, összehangolásában az önkormányzatnak kell szerepet vállalni, illetve segítséget nyújtani. Az adott testület és hivatal irányítási modellje határozza meg az önálló csoport, felelös telepítését. A lényeg az, hogy ezen egység átlássa a település müködését, jól ismerje annak fejlesztési irányait és az sem elhanyagolható, hogy rendelkezzék marketing ismeretekkel.

- A település akkor müködik sikeresen, ha nemcsak az egyes célcsoportok érdekeit képes összehangolni, s azok eredöjeként fejlesztési célokat és irányokat megjeleníteni, hanem akkor, amikor képes reagálni a változó környezetre, sőt orientálni tudja annak elmozdulását. A marketing szemléletủ településfejlesztéssel és irányítással az önkormányzatok, S az egész település müködésének eredményességét növelhetjük, miközben a rendszer alkalmazkodóképességének fokozásával a település jövőjének alakítása befolyásolható. 


\section{Irodalom}

Bányai J. (1993, 1994) Önkormányzatok és marketing 1-11. Comitatus, 11-12. 120-138., 54-58.o.

Cséfalvay Z. - Fischer W. (1990) Cigányzene és lakáshiány - sztereotípiák és a valóság ellentéte a Budapest képben. Földrajzi Értesító, 39. 1-4. 207-220. o.

Kotler, P. (1991) Marketing management. Elemzés, tervezés, végrehajtás és ellenõrzés. Müszaki Kiadó, Budapest.

Maier, J .- Troeger-Weiss G. (1990) Marketing in der räumlichen Planung - Ansätze und Wege zu einer marktorientierten Regional- und Kommunalplanung politik. In: Akademie für Raumforschung und Landesplanung. Heft 117. 152. o.

Meffert, H. (1989) Städtemarketing-Pflicht oder Kür. Planung und Analyse, 8. 273-280. o.

Puskás F. (1994) A városimage szerepe a településfejlesztésben. Diplomanunka Széchenyi 1stván Fóiskola, Györ.

Schaller, U. (1993) City-Management, City-marketing, Stadtmarketing, Allheilmittel für die Innenstadtentwicklung? In: Arbeitmaterialien zur Raumordnung und Raumplanung. Universităt Bayreuth, Bayreuth, 137. 0 .

Schelte, J. (1991) Stadtmarketing und City-Management. In: Dortmunder Materialien zur Raumplanung. Heft 17. Dortmund, 114. o.

Szakál Gy. (1993) Ember és környezet viszonya a győri polgárok tudatában. Mũhely, 1. 43-49. o. 